\title{
TARI TUMATENDEN: BENTUK KOREOGRAFI DAN FUNGSINYA BAGI MASYARAKAT AIRMADIDI MINAHASA UTARA (SEBUAH PENELITIAN ETNO ART)
}

\section{Sri Sunarmi dan Grace Luntungan}

Universitas Negeri Manado, Indonesia

Email: srisunarmi@unima.ac.id, graceluntungan@unima.ac.id

\begin{abstract}
This study aims to shows how the role and existence of Tumatenden Dance in Airmadidi North Minahasa. The aim is to take inventory of local cultural and artistic works, so that with this form, the younger generation will easily demonstrate Local Regional Dance and are motivated to be able to learn and love their own culture, especially traditional regional dance as Local Regional dance. Qualitative descriptive research method with the Ethno Art approach. The role and existence, are used to describe the form of choreography by understanding the phenomena that have become the awareness of the people of North Minahasa, in relation to the role of the Tumatenden Dance in the midst of the society. This approach could inspect and reveal two answers in this study. The formulation can show the form of the choreography of the Tumatenden Dance as a form of populist creation dance, which is performed by nine (9) female dancers, and one male dancer, the Tumatenden dance presentation is a dance that elevates Minahasa folk legends which tell about angels who descended into earth from heaven to bathe in the Tumatenden spring. An interested Minahasan youth tried to win the heart of one of these angels by stealing his wings. This made the angel unable to return to heaven and then married the young man.,
\end{abstract}

Keywords: tumatenden dance; choreography; function; north minahasa
Abstrak
Tujuan penelitian ini yaitu untuk memperlihatkan mengenai bagaimana wujud koreografi Tari Tumatenden, serta menunjukkan Bagaimana peranan dan keberadaan Tari Tumatenden diAirmadidi Minahasa Utara. Tujuannya menginventarisasi karya seni-budaya lokal, Sehingga dengan adanya wujud tersebut maka, generasi muda akan mudah memperagakan Tari Daerah Setempat dan terpacu untuk dapat belajar serta mencintai budaya miliknya khususnya seni tari tradisional daerah sebagai tari Daerah Setempat. Metode penelitian diskriptif kwalitatif dengan pendekatan, Etno Art. Peranan dan keberadaan, dipakai untuk menggambarkan wujud koreografi dengan memahami fenomena yang menjadi kesadaran masyarakatAirmadidi Minahasa Utara, kaitannya dengan peranan keberadaan Tari Tumatenden ditengah- tengah masyarakatnya. Pendekatan ini dapat melihat dan mengungkap dua jawaban dalam penelitian ini. Rumusan dapat menunjukkan wujud koreografi Tari Tumatenden sebagai bentuk tari kreasi kerakyatan, yang dilakukan oleh Sembilan

$\begin{array}{ll}\text { How to cite: } & \text { Sunarmi, Sri., dan Grace Luntungan (2021) Tari Tumatenden: Bentuk Koreografi dan Fungsinya Bagi } \\ & \text { Masyarakat Airmadidi Minahasa Utara (Sebuah Penelitian Etno Art). Syntax Literate. 6(5). } \\ & \text { http://dx.doi.org/10.36418/syntax-literate.v6i5.2740 } \\ \text { E-ISSN: } & \text { 2548-1398 } \\ \text { Published by: } & \text { Ridwan Institute }\end{array}$


(9) penari putri, dan satu penari laki-laki, Sajian tari Tumatenden merupakan tari yang mengangkat cerita legenda rakyat Minahasa yang meceritakan tentang bidadari-bidadari yang turun ke bumi dari kayangan untuk mandi di mata air Tumatenden. Seorang pemuda Minahasa yang tertarik berusaha untuk memikat hati salah satu bidadari tersebut dengan mencuri sayapnya. Hal ini membuat sang bidadari tidak dapat kembali ke kayangan dan kemudian menikah dengan pemuda tersebut..

Kata Kunci: Tari Tumatenden; Koreografi; Fungsi; Minahasa Utara

\section{Pendahuluan}

Kebudayaan adalah suatu bentuk kehidupan dari sekelompok orang yang disebut masyarakat, dan keberadaannya merupakan hasil dari proses kehidupan masyarakat sebelumnya yang berkembang menurut tuntutan sejarahnya sendiri- sendiri (Kayam, 1981). Oleh karena itu, tiap-tiap daerah memiliki karakteristik sosial-budaya yang berbeda-beda. Budaya masing-masing daerah memberikan gambaran umum kehidupan masyarakat di tiap-tiap daerah. Oleh karena itu, tiap-tiap daerah memiliki karakteristik sosial-budaya yang berbeda-beda. Budaya masing-masing daerah memberikan gambaran umum kehidupan masyarakat di tiap-tiap daerah. Budaya atau Kultur menurut (Marzali, 2014) merupakan daya atau kapabilitas dari unsur-unsur intelektual, emosional, dan spiritual bangsa Indonesia yang berfungsi dalam meningkatkan harkat kemanusiaan bangsa Indonesia. Selain itu nilai nilai budaya lokal dapt digunakan untuk menjawab berbagai tantangan yang ada sebagai wujud nyata revitalisasi budaya lokal itu. Bahkan tidak hanya mampu menjawab berbagai tantangan ke depan, namun kearifan lokal itu dapat dijadikan sebagai perekat sekaligus memperkokoh identitas bangsa (Brata, 2016).

Seperti halnya budaya dan kesenian yang ada didaerah Airmadidi Minahasa Utara. Minahasa Utara juga sama dengan daerah-daerah lain yang memiliki budaya yang berbeda dengan daerah atau suku etnik lainya. Budaya agama, perilaku maupun budaya berkesenian juga berbeda dengan budaya daerah yang lain. Namun dalam perkembangan budaya diMinahasa Utara, kesenian, moralitas dan agama, serta perilaku pada hakekatnya merupakan satu kesatuan yang tidak dapat dipisahkan. Salah satu bagian dari kebudayaan adalah kesenian, itulah sebabnya kesenian tidak dapat dipisahkan dari perjalanan kehidupan masyarakat Indonesia.

Kesenian adalah salah satu unsur yang menyangga kebudayaan. (Kayam, 1981). Kesenian yang merupakan warisan turun temurun secara berkesinambungan adalah kesenian tradisional. Kesenian tidak pernah berdiri lepas dari masyarakat. Sebagai salah satu bagian yang penting dari kebudayaan, karena, kesenian merupakan ungkapan kreativitas dari masyarakatnya itu sendiri. Seni merupakan sebuah fenomena kebudayaan yang selalu ada dalam kehidupan manusia. Tidak ada kebudayaan masyarakat mana pun di dunia ini yang di dalamnya tidak mengakomodasi kehadiran seni sebagai bagian integral kehidupan. Hal ini menyiratkan bahwa seni merupakan salah satu kebutuhan manusia yang bersifat universal (Triyanto, 2018). Kesenian di Indonesia dapat di kelompokkan menjadi beberapa bagian seperti; Seni Rupa, Seni Tari, 
Seni Musik, Seni Drama, dan lain sebagainya. Setiap daerah di Indonesia memiliki jenis kesenian masing-masing, dan ekspresi kesenian di tiap-tiap daerah itu merupakan pencitraan atau merupakan cerminan dari kondisi perkembangan kebudayaan daerah tersebut. Kesenian, pada umumnya secara tidak langsung dipakai sebagai sarana untuk pengembangan budaya masyarakat setempat dalam hubungannya dengan sistem budaya itu sendiri (Kaunang \& Sumilat, 2015). Salah satu bagian dari kesenian adalah Seni Tari. Sedyawati menyatakan bahwa tari adalah salah satu pernyataan budaya. Oleh karena itu maka sifat, gaya dan fungsi tari selalu tak dapat dilepaskan dari kebudayaan yang menghasilkannya (Khutniah \& Iryanti, 2012);(Khutniah, 2013) Seni Tari ada bermacammacam jenisnya, salah satu dari jenis tari adalah Tari Tradisional.

Tari Tradisional merupakan jenis tarian yang tumbuh dan berkembang karena tradisi lingkungannya serta yang bersifat turun temurun secara berkesinambungan. Tari tradisional mempunyi ciri dan karakteristik yang berbeda-beda sesuai daerah-daerah dimana tumbuh dan berkembang. Sehingga Tari Tradisional dapat mencerminkan kehidupan daerah serta mencerminkan kekayaan harta warisan budaya bangsa Indonesia. Tarian tradisonal dapat terungkap ciri-ciri tertentu khas daerah yang bersangkutan, yang berbeda dengan daerah-daerah yang lain. Oleh sebab itu tari tradisional merupakan tari yang sangat memegang peranan penting dalam kehidupan masyarakatnya. Salah satu wujud seni atau kesenian yang ada diMinahasa Utara, sebagai sarana dalam pengembangan budaya tersebut adalah Tari Tumatenden

Tari Tumatenden merupakan tari tradisional yang dipergakan secara kelompok. Tari kelompok ini dipergakan dan ditampilkan oleh sembilan penari putri dan satu penari pria dengan menggunakan property selendang. Tari Tumatenden di Airmadidi kabupaten Minahasa Utara merupakan tarian yang sejak dulu sampai sekarang masih selalu dipentaskan sebagai sarana pelengkap upacara, atau sebagai sarana hiburan dalam berbagai acara atau hajatan. Tari Tumatenden biasa dimainkan disetiap acara atau hajatan baik formal maupun non formal didaerah Sulawesi Utara. Tari Tumatenden di Airmadidi Minahasa Utara merupakan tari yang dijadikan sebagai ikon darehah Airmadfidi Minahasa Utara, sehingga setiap ada hajatan baik hajatan secara formal maupun non formal selalu ditampilkan. (Pius, wawancara: 5 Desember 2017).

Tari Tumatenden di Airmadidi Minahasa Utara merupakan tari tradisional sebagai warisan dari pendahulu yang secara turun temurun, sampai pada dewasa ini, serta masih eksis dan masih selalu ditampilkan dalam setiap acara-acara atau hajatan didaerahnya. Sepertinya Tari Tumatenden di Airmadidi Minahasa Utara mempunyai peranan yang sangat penting dalam kehidupan masyarakat di daerah Airmadidi Minahasa Utara. Selain hal tersebut Tari Tumatenden juga merupakan tari yang dapat mencerminkan ciri khas daerah di Airmadidi Minahasa Utara. Karena dengan melihat penampilan Tari Tumatenden, maka sudah pasti akan terlihat bahwa tarian tersebut berasal dari daerah Airmadidi Minahasa Utara. Oleh sebab itu tari Tumatenden merupakan tari tradisional yang dijadikan ikon budaya daerah kabupaten Minahasa Utara ( Kawengian, wawancara: 23 Juli 2016 ).

Sebagai cerminan yang dapat menunjukkan identitas serta ciri khas daerah, maka Tari Tumatenden di Airmadidi Minahasa Utara merupakan aset daerah stempat. Tari Tumatenden di Airmadidi Minahasa Utara sebagai aset budaya daerah, maka sangatlah perlu untuk dijaga, dilestarikan serta dikembangkan. Perkembangan baik dalam perkembangan kwalitas maupun perkembangan dalam penyebarluasan agar lebih bisa dikenal oleh khalayak yang lebih luas lagi. 
Namun dengan adanya, kemajuan tehnologi di jaman Globalisasi sekarang ini telah banyak menjanjikan dan memberikan pesona yang baru kepada masyarakat, sehingga banyak seni-seni atau tari-tari yang hilang atau punah karena telah dipengaruhi globalisasi tersebut. Pola perubahan hidup yang baru lebih menawarkan cita-rasa yang terkesan lebih maju dibandingkan dengan cita-rasa ekspresi budaya lokal. Sehingga, anak-anak muda khususnya anak-anak sekolah karena berbagai macam sebab lebih terpesona dengan aneka gaya, pola dan cara hidup global, dan tidak tertarik dengan budayanya sendiri. Pernyataan ini mengindikasikan adanya suatu kecemasan masyarakat dalam menatap kelangsungan hidup tari tari tradisional, sebagai tradisi budaya miliknya.

Kebudayaan merupakan seluruh karya cipta manusia yang terdiri dari sistem religi dan upacara keagamaan, sistem organisasi kemasyarakatan, sistem pengetahuan bahwa Kesenian, sistem mata pencaharian hidup, sistem teknologi dan peralatan (Koentjaraningrat, 1981). Kemajuan tehnologi di jaman yang telah modern atau jaman globalisasi sekarang ini, maka sebagai bangsa Indonesia berkewajiban untuk menjaga, melestarikan serta mengembangkannya ke dunia yang lebih luas. Artinya, demi kemajuan jaman tidak menampik kemajuan tehnologi namun perlu adanya usaha atau sikap yang lebih selektif mungkin, serta berkewajiban untuk menjaga seni-seni tradisional khususnya tari-tari tradisional yang ada di Indonesia ini. Seperti dijelaskan oleh Kartodirjo, dalam buku penelitian dan pengembangan Historiografi Indonesia suatu Alternatif, bahwa : "Modernisasi bukan berarti keharusan untuk membuang atau menghilangkan nilai-nilai masa lampau atau tradisonal, karena masih banyak yang relevan dan telah diuji secara empiris sehingga tidak lapuk olah jaman " (Sartono, 1982).

Berdasarkan hal tersebut, perlu adanya suatu usaha pelestarian dengan mengadakan suatu usaha penggalian serta usaha dalam hal pengembangan budaya atau kesenian. Khususnya Tari Tumatenden yang ada di Airmadidi Minahasa utara.

Ada beberapa penelitian terdahulu sekaitan dengan Tari Tumatenden tapi berbeda dari segi bentuk kajian yang dilakukan. (Mangangue, 2019) mengkaji ungkapan verbal dan nonverbal bermakna budaya dalam Tari Tumatenden dari segi kajian linguistik antropologi; (Ferdine, Egam, \& Moniaga, 2018) merancang fasilitas rekreasi berupa taman Tumatenden tematik yang mengandung unsur budaya sekaligus sebagai edukasi seni budaya yang bertema cerita legenda Tumatenden; Oleh sebab itu tampak gejala yang menarik untuk dicermati, serta dijadikan permasalahan yang menjadi pokok perhatian penelitian. Adapun masalah tersebut dapat dirumuskan sebagai berikut: Bagaimana wujud koreografi Tari Tumatenden? dan lebih jauh, Bagaimana peranan keberadaanTari Tumatenden?

\section{Metode Penelitian}

Penelitian ini bersifat kualitatif dengan beberapa pendekatan pada Tari Tumatenden yang dibingkai pada "literatur lisan" dan dipahami sebagai suatu teks, untuk memunculkan verbalitas dengan berbagai konsepsi Etno Art Fenomenologi (Ahimsa Putra, 2002) peranan keberadaan tari Tumatenden ditengah-tengah kehidupan masyarakat Minahasa Utara. Pendekatan tersebut dipakai untuk memahami fenomena yang menjadi kesadaran untuk mengungkap koreografis serta Keberadaan Tari Tumatenden. Informasi seniman Tumatenden ataupun data-data audio dan/atau audiovisual akan dipahami sebagai suatu dokumen yang terbuka untuk didiskrepsikan. Keberadaan atau kehidupan sebuah kebudayaan atau kesenian sangat di tentukan oleh kondisi lingkungan masyarakat pendukunganya (Kayam, 1981). 
Pemikiran umar Kayam tersebut untuk melihat keberadaan Tari Tumatenden serta untuk mendapatkan gambaran Tari Tumatenden dalam kehidupan masyarakat Minahasa Utara. Koentjaraningrat mengatakan bahwa manusia sebagai pendukung kebudayaan, terdiri dari latar belakang kebudayaan yang berbeda-beda. Mereka saling bergaul langsung secara intensif untuk waktu yang lama sehingga kebudayaan-kebudayaan tersebut berubah sifatnya yang khas serta berubah wujudnya menjadi unsur-unsur kebudayaan campuran.

Berdasarkan teori-teori yang dikemukakan diatas, dapat digunakan sebagai acuan atau landasan serta sebagai pendukung dalam penelitian ini. Selain itu dalam penelitian ini juga lebih memperhatikan kesadaran dan minat masyarakat tehadap Tari Tumatenden yang merupakan salah satu kesenian tradisional daerah Minahasa Utara. Hal ini juga dengan memperhatikan bagaimana munculnya Tari Tumatenden ditengahtengah masyarakatnya, serta bagaimana Tari Tumatenden itu digunakan oleh masyarakat Minahasa Utara khususnya Airmadidi.

\section{Hasil dan Pembahasan}

\section{A. Bentuk Koreografi Tari Tumatenden}

Dilihat dari arti nama Tari Tumatenden yang berasal kata " "Tendens", yang artinya sandaran hidup, sedangkan kata "Tuma", yang artinya "tempat" berdasarkan bahasa Tonsea dapat diartikan bahwa Tumatenden dapat diartikan " tempat sandaran hidup". Secara koreografis Tari Tumatenden merupakan tari yang ditampilkan oleh sembilan penari putri dan satu penari pria dengan menggunakan property selendang. Unsur-unsur Tari Tumatenden sangat sederhana, namun didalamya terkandung pesan etika yang disampaikan dalam bermasyarakat dan juga dalam kehidupan berumah tangga yang harus selalu saling menghargai privasi dari suami istri.

Jumlah penari berjumlah Sembilan penari putri dan satu penari pria . Penarpenari wanita atau putri dalam tampilannya menggunakan tata busana maupun tatariasnya selalu sama atau seragam. Sehingga nampak seperti wanita kembar. Medium-medium gerak yang digunakan sangat sederhana. Penari-penari tersebut menampilkan gerakan- gerakan yang sama dengan lemah gemulai berputar-putar sambil membuat formasi-fomasiatau pola lantai .

Demikian juga elemen-elemen yang digunakanpun sangat sederhana pula. Tari Tumatenden ditampilkan secara berkelompok, jumlah penari selalu berjumlah sembilan penari putri atau wanita dan ditambah satu penari pria. Dalam Tari Tumatenden ditampilkan penokohan penggambaran sembilan bidadari yang turun dari khayangan untuk melakukan kegiatan mandi dikolam dan satu penari pria sebagai penggambaran tokoh Mamanua sebagai tokoh penduduk kampung yang terperanjat menyaksikan sembilan bidadari yang berenang-renang dikolam. Dari sembilan penari bidadari ada satu yang menjadi tokoh putri bungsu dari kesembilan saudara bidadari yang dinamakan Lumalundung. Yang akhirnya antara Lumalundung dan Mamanua menikah dan menjadi suami istri, berkat pencuruian sayap Lumalundung yang dicuri oleh Mamanua. 
Pola-pola gerak yang digunakan sangat sederhana, yaitu menggunakan vokabuler gerak yang gampang dilakukan artinya, tidak mempunyai tingkat kesulitan. Gerakannya dilakukan dengan cara yang sangat sederhana. Namun, pengamatan sehari-hari menunjukkan bahwa anggota badan yang digunakan sebagai medium paling dominan adalah tangan sambil memegang memainkan selendang dibandingkan dengan kaki. Sebab dominasi gerak yang paling menonjol adalah gerak tangan dari pada gerakan kaki. Gerakan kaki seolah-olah cuma bergerak silang-silang dan lebih banyak gerak jalan dengan langkah kecil-kecil dan jinjit-jinjit.

Adapun vokabuler-vokabuler gerak tersebut antara lain: yaitu, gerak masuk pentas atau pembuka dengan menggunakan gerakan terbang ( Sumendow), gerak berenang (Mokyow), gerak bekerja (Makyang), gerakan menenam ( Tumanem), gerakan mandi (Lele ), gerak bermain (Lumeong), gerak Menangis/sedih( Mamek), gerakan lari,( Teitei ), gerak jalan ( Kelang ), gerakan berkumpul ( Makuwu ), gerakan Lompat ( Sengkot ), dan gerakan hormat ( Sighi). ( Wawancara, Emmy Indy: 5 Juli 2012 )

Volume gerak yang digunakan banyak menggunakan volume yang luas tetapi pada gerakan tangan yang diputar-putar atau ukel-ukel ebih banyak menggunakan volume yang sempit. Bntuk-bentuk gerak Tari Tumatenden lebih bersifat dinamis serta bersifat artistik sering kali sangat dipertimbangkan. Gerak kaki, tangan, maupun ungkapan-ungkapan verbal yang terekspresi lewat gerakan maknawi yang terangkai dalam tempo dan irama yang tetap, ajeg, yang ditentukan oleh irama musik iringan tarinya.

Dalam kaitannya dengan musik, terdengar suara iringan instrument yang disebut kolintang dan suara suling sebagai melodi, juga suara alat perkusi tambur . Irama yang digunakan dalam tari Tumatenden sepertinya mengalun lembut, mengalir serta sedikit ada tekanan-tekanan dan sepertinya kelihatan monoton dan beriramakan melankolis. Tempo yang ada pada tari Tumatenden kelihatan teratur mengikuti irama yang melankolis namun selalu tampak ceria. Musik Iringan tari merupakan sesuatu yang selalu mendampingi dalam tarian dan berfungsi sebagi pengiring untuk membantu mengungkapkan penjiwaan yang ada dala ttariannya. Dalam tari Tumatenden lebih bersifat monoton dan selalu paralel,. Namun dalam irama bisa dirasakan lebih dinamis, Alat musik iringan yang digunakan juga sangat sederhana. artinya alat yang digunakan yaitu suling, tambur dan dikombinasikan dengan alat musik tradisional daerah Minahasa yaitu musik kolintang.( Wawancara, Roy Kumaat, Pelatih Tari Tumatenden: 10 Juli 2015).

Tata rias dan busana juga sangat sederhana yaitu menggunakan kostum atau pakaian yang biasanya berwarna polos dan berbentuk rok terusan, atau hampir mirip model duyung dengan dipadsukan kebaya dan ada juga menampilkan seperti baju -baju pesta. Adapun kostum yang digunakan tersebut diberikan aksen assesories , baik manik-manik maupun renda-renda keemasan dan banyak dihiasi manik-manik yang gemerlap karena lebih pada penggambaran bidadari dari 
khayangan. Sedangkan Kostum yang digunakan penari pria menggunakan celana kombrang dan baju tanpa lengan. kostum pria berwarna polos juga atau tanpa motif namun dihiasi renda-renda atau pita untuk aksen pemanis. Selain itu juga penari pria menggunakan pelngkap kostum yaitu memakai topi layaknya topi-topi yang digunakan oleh para petani dikebun atau disawah. Adapun rambut atau busana pada kepala penari putri adalah rambut terurai kebawah namun diusahakan tetap rapi dan menggunakan sanggul atau diatur seperti sanggul kecil. Aksessories kepala yang digunakan adalah sunting atau cunduk kembang goyang dan juga hiasan bunga- bunga bisa bunga segar dan juga bunga-bunga plastik sebagai pemanis. Selain itu juga dilengkapi assesories serta anting atau giwang dan juga gelang.

Dalam tarian ini property yang digunakan adalah selendang sebagai penggambaran sayap bidadari. Property adalah alat perlengkapan yang dipergunakan oleh penari diatas pentas atau panggung, yang digunakan untuk memperjelas tema serta maksud yang akan disampaikan (Sri Sunarmi, 2019). Pola lantai yang digunakan juga sangat sederhana sekali. Pola lantai yang digunakan dalam tari Tumatenden selalu berbentuk simetris serta menampilkan bentuk-bentuk formasi tertentu. Adapun pola lantainya adalah pola lantaiyang sangat sedrhana yaitu formasi lingkaran, formasi berbaris sejajar, formasi segi tiga serta formasi berbentuk" V" dan sebagainya.

\section{B. Fungsi Tari Tumatenden Bagi Masyarakat Airmadidi Minahasa Utara}

Tari Tumatenden dapat dikatakan sebagai suatu wujud seni tradisional rakyat. Eksistensinya tampak dan hidup secara turun temurun dari generasi ke generasi hingga sekarang. Tari Tumatenden juga telah dikembangkan sedemikian rupa, dan bahkan berkembang menjadi suatu bentuk kesenian yang mepresentasikan ciri atau khas bahkan dijadikan sebagai ikon daerah Minahasa Utara

Keberadaan Tari Tumatenden pada waktu dulu dan sekarang tidak ada perbedaannya. Hal ini bisa dikatakan demikian karena menurut bebrapa pihak yang telah diwawancarai bahwa Tari Tumatenden dahulu sampai sekarang masih tetap eksis dalam kehidupan bermasyarakat diAirmadidi Minahasa Utara. Artinya bahwa,Tari Tumatenden di Airmadidi Minahasa Utara selalu ditampilkan pada setiap acara atau hajatan apapun. Tari Tumatenden di Airmadidi Minahasa Utara merupakan tari tradisional sebagai warisan dari pendahulu yang secara turun temurun, sampai pada dewasa ini, serta masih eksis dan masih selalu ditampilkan dalam setiap acara-acara atau hajatan didaerahnya.

Sepertinya Tari Tumatenden di Airmadidi Minahasa Utara mempunyai peranan yang sangat penting dalam kehidupan masyarakat di daerah Airmadidi Minahasa Utara. Selain hal tersebut Tari Tumatenden juga merupakan tari yang dapat mencerminkan ciri khas daerah di Airmadidi Minahasa Utara. Karena dengan melihat penampilan Tari Tumatenden, maka sudah pasti akan terlihat bahwa tarian tersebut berasal dari daerah Airmadidi Minahasa Utara. Oleh sebab itu tari Tumatenden merupakan tari tradisional yang dijadikan ikon budaya daerah kabupaten Minahasa Utara (Kawengian, wawancara: 23 Juli 2018). 
Sebagai cerminan yang dapat menunjukkan identitas serta ciri khas daerah, maka Tari Tumatenden di Airmadidi Minahasa Utara merupakan aset daerah stempat. Tari Tumatenden di Airmadidi Minahasa Utara sebagai aset budaya daerah, maka sangatlah perlu untuk dijaga, dilestarikan serta dikembangkan. Perkembangan baik dalam perkembangan kwalitas maupun perkembangan dalam penyebarluasan agar lebih bisa dikenal oleh khalayak yang lebih luas lagi. Pelestarian sebagai kegiatan atau yang dilakukan secara terus menerus, terarah dan terpadu guna mewujudkan tujuan tertentu yang mencerminkan adanya sesuatu yang tetap dan abadi, bersifat dinamis, luwes, dan selektif. Pelestarian budaya adalah upaya untuk mempertahankan nilai-nilai seni budaya, nilai tradisional dengan mengembangkan perwujudan yang bersifat dinamis, luwes dan selektif, serta menyesuaikan dengan situasi dan kondisi yang selalu berubah dan berkembang (Nahak, 2019).

Pembahasan mengenai peranan keberadaan Tari Tumatenden pada waktu dahulu dan pada dewasa ini, tidak ada perbedaan. Tari Tumatenden pada waktu dahulu sampai sekarang sangat menjadi idola serta menjadi kebanggaan masyarakat daerah Airmadidi Minahasa Utara. Hal ini dikarenakan setiap ada penampilan Tari Tumatenden itu akan menunjukkan atau sudah dapat dimengerti oleh orang-orang bahwa itu Tarian yang berasal dari daerahMinahasa Utara. Selain hal tersebut, bahwa Tari Tumatenden merupakan ciri khas serta sudah menjadi suatu identitas daerah Airmadidi Minahasa Utara.

Tari Tumatenndens di Airmadidi Minahasa Utara dari dahulu sampai sekarang memiliki peranan yang sangat penting. Tari Tumatenden pada waktu dahulu sampai dewasa ini digunakan pada ivent-ivant penting seperti ; penyambutan tamu baik secara formal maupun non formal, acara resepsi kenegaraan, serta dipakai atau ditampilkan untuk acara hiburan masyarakat sampai pada tingkat ivent-ivent perlombaan.

Penampilan Tari Tumatenden dapat menarik perhatian bagi orang yang menyaksikannya. Apalagi didukung dengan kostum atau pakaian yang digunakan juga sangat menarik perhatian karena lebih kelihatan sangat megah dengan assesories warna-warna polos kontras penuh kemegahan, layaknya bidadari dari khayangan yang turun kebumi.

Tari Tumatenden di Airmadidi sudah menjadi identitas masyarakat daerahMinahasa Utara, karena sajian Tari Tumatenden sudah mentradisi pada kehidupan masyarakat Minahasa Utara. ( Wawancara,Pius : 3 Juni 2017). Namun demikian karena di jaman yang sudah modern dan jaman yang Globalisasi yang penuh dengan tantangan pola hidup yang serba baru, Tari Tumatenden tetap dan selalu menjadi tampilan yang paling utama. Padahal pola hidup yang serba baru selalu memberikan suatu yang lebih, namun Tari Tumatenden tidak berpengaruh atau bergeser sedikitpun. Karena ini dapatlah dilihat disetiap ada acara atau hajatan apapun yang ada di Minahasa Utara khussnya di Airmadidi selalu diadakan penampilan dan pementasan Tari Tumatenden. 
Dengan adanya suatu perkembangan pada masyarakat di Minahasa Utara dalam sistem informasi, tehnologi, maupun hiburan, maka timbulah suatu perubahan yang membuat masyarakat ingin mencoba hal-hal baru. Hal ini merupakan hal yang sangat normal dalam suatu perubahan kebudayaan. Namun dengan datangnya pola-pola yang baru bagi masyarakat Minahasa Utara tidak merasa terpengaruh dengan sesuatu yang baru, hal ini bukan berarti masyarakat daerah Minahasa Utara tidak meneriama hal-hal yang lebih baru, namun bagi masyarakat setiap bertindak harus selalu mengadakan kegiatan lebih selektif.

Sehingga kebudayaan yang lama merasa tidak bisa digeser oleh apapun. Oleh sebab itulah Tari Tumatenden didaerah Minahasa Utara khususnya di Airmadidi masih tetap dominan peranannya dalam kehidupan masyarakat (Wawancara:Dofi Pantow, Weku, 5 Juni 2012 ).

Namun di jaman yang telah modern ini juga sangat mempengaruhiTari Tumatenden. Tetapi pengaruh tersebut bukanlah pengaruh dari peranan Tari Tumatenden dalam kehidupan masyarakatAirmadidi, namun lebih pengaruh yang lebih untuk menuju ke sesuatu yang lebih baik. Artinya, bahwa perubahanperubahan itu adalah demi kebaikan pada bobot kwalitas dari Tari Tmatenden sebagai pertunjukan yang lebih artistik. Sesuatu yang baru itu dalam segi penyajian, atau penampilannya, yaitu para kreator, para penari lebih memperhatikan bobot kwalitas penampilannya baik secara fisik maupun secara dinamik. Hal ini dapat dilihat dari penampilan yang secara tehnik kesenian lebih diperhatikan.

Adapun tehnik-tehnik kesenian tersebut diantaranya yaitu dari segi gerak sebagai medium pokok sangat diperhatikan dalam hal elemen-elemen geraknya Seperti misalkan kejelasan pada, bentuk, volume, garis, irama serta ekspresi dalam vokabuler gerak sangat diperhatikan. Selain hal tersebut juga dari segi medium pendukungnya, diantaranya dari segi tata rias serta serta penataan busana sebagai kostumyang digunakan pada Tari Tumatenden. Dalam segi penampilan kostum yang mengalami beberapa perubahan, artinya busana yang dulu sangat sederhana sekarang lebih didesain baik dari bahan yang digunakan, maupun dalam penataan desain model baju sebagai kostumnya. Penataan - penataan tersebut dibuat lebih bisa menarik perhatian, baik bagi yang melihat maupun yang memekainya,

Jadi, Perubahan tersebut merupakan perubahan pada tingkat perkembangan kreatifitas tehnik kesenian. Hal ini dapat dilihat dalam penggarapan pada gerakangerakan tari. Pada gerakan tari sekarang lebih menarik serta lebih kelihatan lincah serta dinamik. Sehingga membuat lebih manarik dalam penyajiannya. Mengenai fungsi seni pertunjukan atau penampilan Tari Tumatenden dari dahulu hingga sekarang sebenarnya masih sama.

\section{Sosialisasi.}

Penjelasan gambaran wujud koreografi dan peranan keberadaan Tari Tumatenden di Airmadidi tersebut disosialisasikan kepada mahasiswa sebagai wujud usaha pengembangan bahan ajar pada mata kuliah Tari Daerah Setempat serta sebagi wujud apresiasi seni bagi mahasiswa konsntrasi seni tari Prodi 
Sendratasik FBS UNIMA. Wujud dari koreografis dan peranan keberadaan fungsi Tari Tumatenden di Airmadidi Minahasa Utara tersebut dijelaskan kepada mahasiwa konsentrasi seni tari di UNIMA, agar mahasiwa bisa dan mampu memperagakan tari Tumatenden dengan baik dan benar. Selain itu mahasiswa bisa mempunyai kepekaan rasa estetik serta mempunyai rasa menghargai terhadap wujud-wujud karya seni yang ada di Indonesia, terutama wujud-wujud karya seni yang ada didaerah setempat. Sehingga mahasiswa khususnya mahasiswa seni tari di UNIMA bisa mempunyai rasa penghargaan dan kepekaan terhadap budaya miliknya.

Diharapkan mahasiswa juga mempunyai rasa bangga terhadap budaya miliknya, betapa penting dan berharganya budaya daerah setempat khususnya taritari tradisional. Karena tari-tari tradisional merupakan ciri serta identitas dimana tari itu tumbuh dan berkembang pada suatu daerahnya. Selain hal tersebut sosialisasi ini juga merupakan salah satu wujud pengembangan dan pelestarian budaya seni lokal. Budaya seni lokal perlu untuk dikembangkan baik secara kualitas maupun secara penyebarluasan. Oleh sebab itu hal ini perlu disoaialisasikan karena seni budaya lokal khususnya seni tari tradisional merupakan ciri dan karakter dari kekhasan budaya daerah dimana tari tradisional itu tumbuh dan berkembang dan mengalami perubahan. Perubahan dalam dunia pendidikan seni, seperti halnya seni tari adalah wajar. Karena usaha itu merupakan suatu bukti adanya semangat untuk membentuk atau mencipta, dengan mencipta berarti melakukan suatu perubahan, hanya saja dalam berbagai perubahan selalu memunculkan gaya dan warna yang mengiringi perubahan tersebut, hal ini mungkin terlihat pada pola garap, trend, teknik dan gagasan yang menembus batasbatas geografis dan kultural (Indrayuda, 2015).

\section{Kesimpulan}

Tari Tumatenden sebagai sebuah karya tari tradisional yang merupakan suatu budaya yang sangat menarik untuk di pertahankan serta dilestarikan. Secara koreografis Tari Tumatenden merupakan tari yang ditampilkan oleh sembilan penari putri dan satu penari pria dengan menggunakan property selendang. Unsur-unsur Tari Tumatenden sangat sederhana, namun didalamya terkandung pesan etika yang disampaikan dalam bermasyarakat dan juga dalam kehidupan berumah tangga yang harus selalu saling menghargai privasi dari suami istri. Dilihat dari arti nama Tari Tumatenden yang berasal kata "Tenden", ang artinya sandarac hidup, sedangkan kata "Tuma", yang artinya "tempat" berdasarkan bahasa Tonsea dapat diartikan bahwa Tumatenden dapat diartikan "tempat sandaran hidup" . Selain dari itu dilihat dari wujud koreografi dan fungsi atau peranan keberadaan Tari Tumatenden merupakan suatu tarian yang dipakai sebagai media pelengkap upacara dan juga segai fungsi hiburan pertunjukan dalam berbagai acara baik secara formal maupun non formal. Tari Tummatenden lebih mengungkapkan rasa kebersamaan, kebahagiaan, harapan, kesuburan, romantika kehidupan erumah tangga dan juga rasa cinta kasih. Medium-medium gerak yang 
digunakan sangat sederhana. Demikian juga elemen-elemen yang digunakanpun sangata sederhana pula.

Tari Tumatenden ditampilkan secara berkelompok, jumlah penari selalu berjumlah sembilan penari putri atau wanita dan ditambah satu penari pria. Dalam Tari Tumatenden ditampilkan penokohan penggambaran sembilan bidadari yang turun dari khayangan untuk melakukan kegiatan mandi dikolam dan satu penari pria sebagai penggambaran tokoh Mamanua sebagi tokoh penduduk kampung yang terperanjat menyaksikan sembilan bidadari yang berenang-renang dikolam. Dari sembilan penari bidadari ada satu yang menjadi tokoh putri bungsu dari kesembilan saudara bidadari yang dinamakan Lumalundung. Yang akhirnya antara Lumalundung dan Mamanua menikah dan menjadi suami istri, berkat pencuruian sayap Lumalundung yang dicuri oleh Mamanua.

Adapun pola-pola gerak yang digunakan sangat sederhana,yaitu menggunakan vokabuler gerak yang gampang dilakukan atau diperagakan, artinya, tidak mempunyai tingkat kesulitan. Tata rias dan busana juga sangat sederhana yaitu menggunakan kostum atau pakaian yang biasanya berwarna polos dan berbentuk rok terusan, atau hampir mirip model duyung dengan dipadukan kebaya dan ada juga menampilkan seperti baju -baju pesta.. Sedangkan Kostum yang digunakan penari pria menggunakan celana kombrang dan baju tanpa lengan. kostum pria berwarna polos juga atau tanpa motif namun dihiasi renda-renda atau pita untuk aksen pemanis. Selain itu juga penari pria menggunakan pelngkap kostum yaitu memakai topi layaknya topi-topi yang digunakan oleh para petani dikebun atau disawah. Adapun rambut atau busana pada kepala penari putri adalah rambut terurai kebawah namun diusahakan tetap rapi dan menggunakan sanggul atau diatur seperti sanggul kecil serta menggunakan assesoriers kepala juga dilengkapi assesories serta anting atau giwang dan juga gelang.

Property yang digunakan adalah selendang sebagai penggambaran sayap bidadari. Formasi pola lantai yang digunakan juga sangat sederhana sekali. Pola lantai yang digunakan dalam tari Tumatenden selalu berbentuk simetris serta menampilkan bentukbentuk formasi tertentu. Musik Iringan tari merupakan sesuatu yang selalu mendampingi dalam tarian dan berfungsi sebagi pengiring untuk membantu mengungkapkan penjiwaan yang ada dala ttariannya. Dalam tari Tumatenden lebih bersifat monoton dan selalu paralel. Namun dalam irama bisa dirasakan lebih dinamis. Alat musik iringan yang digunakan juga sangat sederhana. artinya alat yang digunakan yaitu suling, tambur dan dikombinasikan dengan alat musik tradisional daerah Minahasa yaitu musik kolintang..

Peranan dan keberadaan dari Tari Tumatenden ditengah-tengah kehidupan masyarakat Airmadidi Minahasa Utara dianalisis berdasarkan pendekatan serta landasan teori dari umar Kayam. Adapun penjelasannya adalah mengenai bagaimana peranan dan keberadaan Tari Tumatenden tersebut. Yang diantaranya bahwa, Tari Tumatenden berfungsi sebagai pelengkap acara kegiatan upacara perkawinan, sebagai fungsi hiburan pertunjukan baik pada acara atau hajatan formal maupun non formal. Tari tumatenden di Airmadidi kabupaten Minahasa Utara dari dahulu sampai sekarang memiliki peranan 
Sri Sunarmi dan Grace Luntungan

yang sangat penting bagi masyarakat pendukungnya. Artinya, bahwa Tari Tumatenden pada waktu dahulu sampai pada dewasa ini sama biasa ditampilkan dan digunakan pada ivent-ivent secara formal maupun non formal. 
Tari Tumatenden: Bentuk Koreografi dan Fungsinya Bagi Masyarakat Airmadidi Minahasa Utara (Sebuah Penelitian Etno Art)

\section{BIBLIOGRAFI}

Ahimsa Putra, H. S. (2002). Ethno Art Fenomenologi Seni Untuk Indiginasi Seni dan ilmu. STSI Surakarta: Makalah Seminar Internasional Seni Pertunjukan dan ilmu Pengetahuan Seri II 2002-2004.

Brata, Ida Bagus. (2016). Kearifan budaya lokal perekat identitas bangsa. Jurnal Bakti Saraswati (JBS), 5(1). Google Scholar

Ferdine, Debora, Egam, Pingkan Peggy, \& Moniaga, Ingerid L. (2018). TUMATENDEN PARK. Sustainable Architecture. MEDIA MATRASAIN, 15(2), 1-8. Google Scholar

Indrayuda, Indrayuda. (2015). Tari Tradisional dalam Ranah Tari Populer: Kontribusi, Relevansi, dan Keberlanjutan Budaya. Humanus, 14(2), 144-151. Google Scholar

Kaunang, Ivan Robert Bernadus, \& Sumilat, Mareike. (2015). Kemasan Tari Maengket Dalam Menunjang Industri Kreatif Minahasa Sulawesi Utara Di Era Globalisasi. Jurnal Lppm Bidang Ekososbudkum, 2(1), 89-106. Google Scholar

Kayam, Umar. (1981). Seni, tradisi, masyarakat. Penerbit Sinar Harapan. Google Scholar

Khutniah, Nainul. (2013). Upaya Mempertahankan Eksistensi Tari Kridha Jati di Sanggar Hayu Budaya Kelurahan Pengkol Kecamatan Jepara Kabupaten Jepara. Universitas Negeri Semarang. Google Scholar

Khutniah, Nainul, \& Iryanti, Veronica Eny. (2012). Upaya Mempertahankan Eksistensi Tari Kridha Jati Di Sanggar Hayu Budaya Kelurahan Pengkol Jepara. Jurnal Seni Tari, 1(1). Google Scholar

Koentjaraningrat. (1981). Manusia Dan Kebudayaan Di Indonesia. Jakarta: Djambatan.

Mangangue, Jeane. (2019). Ungkapan Verbal Dan Nonverbal Bermakna Budaya Dalam Tari Tumatenden Masyarakat Tonsea Minahasa: Kajian Linguistik Antropologi. Jurnal Akrab Juara, 4(2), 21-30. Google Scholar

Marzali, Amri. (2014). Memajukan Kebudayaan Nasional Indonesia. Humaniora, 26(3), 251-265. Google Scholar

Nahak, Hildgardis M. I. (2019). Upaya melestarikan budaya indonesia di era globalisasi. Jurnal Sosiologi Nusantara, 5(1), 65-76. Google Scholar

Sartono, Kartodirdjo. (1982). Pemikiran dan Perkembangan Historiografi Indonesia. Jakarta: Gramedia. Google Scholar

Sri Sunarmi, Grace Shirley Luntungan. (2019). The Symbolic Meaning of Song Lyrics and Choreographic Form of the Tombulunese Three-Stage Maengket Dance. 
Sri Sunarmi dan Grace Luntungan

International Journal of Recent Technology and Engineering (IJRTE) ISSN: 22773878, Volume-8(2S9).

Triyanto, Triyanto. (2018). Pendekatan Kebudayaan Dalam Penelitian Pendidikan Seni. Imajinasi: Jurnal Seni, 12(1), 65-76. Google Scholar

\section{Copyright holder :}

Sri Sunarmi dan Grace Luntungan (2021)

First publication right :

Journal Syntax Literate

This article is licensed under:

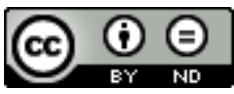

